\title{
Totally chlorine-free bleaching of prehydrolysis soda pulp from plantation hardwoods consisting of various lignin structures
}

\author{
Ayyoub Salaghi ${ }^{1}$, Agusta Samodra Putra ${ }^{1}$, Andri Taufick Rizaluddin ${ }^{2}$, Mikio Kajiyama $^{1}$ and Hiroshi Ohi ${ }^{*}$
}

\begin{abstract}
The process of prehydrolysis followed by soda-anthraquinone (AQ) cooking and totally chlorine-free (TCF) bleaching with peroxymonosulfuric acid $\left(\mathrm{P}_{\mathrm{sa}}\right)$ was investigated to develop a biorefinery process. Eucalyptus globulus, showing a high syringaldehyde $\left(S_{a}\right)$ to vanillin $\left(V_{a}\right)$ molar ratio after nitrobenzene oxidation, was utilized. Xylooligosaccharide yield in the prehydrolysate $\left(\mathrm{PHL}\right.$ ) obtained at $150^{\circ} \mathrm{C}$ for $2.5 \mathrm{~h}$ reached $7.2 \%$ of wood weight, indicating $47 \%$ extraction of xylan. Furfural yields increased with acid catalytic dehydration of the PHL to 1.0-1.8\% of wood weight; adding an earlier acid post-hydrolysis of the PHL to generate monomeric xylose enhanced furfural production to $4.0 \%$. SodaAQ cooking, a non-sulfur process affording simpler alkali lignin isolation than kraft cooking, was utilized. Active alkali dosage increment decreased both $S_{a}$ to $V_{a}$ molar ratio ( $S / N$ ratio) and $S_{a}$ and $V_{a}$ yields of dissolved lignin. Gel permeation chromatography indicated decreased or increased purified lignin weight-average molecular weight $\left(M_{w}\right)$ upon increased active alkali dosage or prehydrolysis temperature, respectively (e.g., 150 to $170{ }^{\circ} \mathrm{C}$ at $18 \%$ alkali increased $M_{\mathrm{w}} 1653$ to 2050$)$. Chlorine dioxide (0.083\% and $0.042 \%$ as active chlorine) inclusion during the 1 st and 2 nd $\mathrm{P}_{\text {sa }}$ stages with $\mathrm{P}_{\mathrm{sa}}\left(0.2 \%\right.$ and $0.1 \%$ as $\mathrm{H}_{2} \mathrm{SO}_{5}$ weight, respectively) improved final bleached pulp viscosity from 6.0 to $7.2 \mathrm{mPa}$ s.
\end{abstract}

Keywords: Prehydrolysate, Furfural, Dissolving pulp, Prehydrolysis soda-AQ cooking, Chlorine-free bleaching

\section{Introduction}

In the biorefinery concept, it is important that cellulose, hemicellulose, and lignin are effectively separated from lignocellulosic raw materials; these three main biopolymers are then converted to basic sources for other value-added materials, chemicals, and fuels. Dissolving pulp (DP), which consists primarily of pure cellulose, is used as a material for manufacturing rayon and cellulose derivatives. DP needs to be produced in a high-quality range, with a high degree of purity $(>94 \%$ $\alpha$-cellulose), an acceptable level of viscosity ( $>6.2 \mathrm{mPa} \mathrm{s})$, and an extremely low lignin content $(0.05 \%)$ [1]. Meeting such requirements renders the yield of the overall

\footnotetext{
*Correspondence: oi.hiroshi.gm@u.tsukuba.ac.jp

${ }^{1}$ Graduate School of Life and Environmental Sciences, University

of Tsukuba, Tsukuba, Japan

Full list of author information is available at the end of the article
}

DP production process relatively low (30-35\%) when compared to that of regular pulps for papermaking use [2]. Therefore, for DP production, a high rate of cellulose purity in addition to acceptable levels of both cellulose yield and viscosity are important factors to be optimized.

In turn, hemicelluloses, which are released by prehydrolysis of lignocellulosic material in the DP production process, are very useful in the biorefinery process. Hemicelluloses in softwoods include arabinoglucuronoxylan, arabinogalactan, and galactoglucomannan, whereas the predominant hemicelluloses in hardwoods are glucuronoxylan and glucomannan [3]. In the prehydrolysis step, the formation of acetic acid from acetyl groups bound to the hemicelluloses raises the hydrolytic cleavage of glycosidic bonds and the subsequent degradation of carbohydrates, particularly hemicelluloses [4, 5]. Furthermore, the severity of the prehydrolysis conditions and an extent of hydrolytic cleavage of glycosidic bonds control the 
remaining amount of partly hydrolyzed cellulose in the raw material residue and its final degree of polymerization [6].

During the prehydrolysis, hemicelluloses and other organics are dissolved in the prehydrolysate (PHL). The major reactions include depolymerization and dissolution of hemicellulose [4, 7], along with further degradation of pentose to products such as furfural and hydroxymethylfurfural [8]. Furfural is a natural dehydration product of xylose, which constitutes glucuronoxylan and glucuronoarabinoxylan. In particular, furfural has been identified as one of the top thirty platform chemicals able to be generated from biomass [9]. Accordingly, numerous studies on the prehydrolysis of lignocellulosic raw materials have been implemented. Li et al. [10] reported that the prehydrolysis conditions, such as time and temperature, should be controlled in order to produce the targeted final products (e.g., oligomeric sugars, monomeric sugars, or furfural). For the purpose of hemicellulose utilization from the prehydrolysis liquor, a prehydrolysis temperature of $170{ }^{\circ} \mathrm{C}$ is optimal. Putra et al. [11] showed that upon $1 \mathrm{~h}$ dehydration of nitric acid PHL with sulfuric acid at $6 \%$ concentration as a catalyst, furfural yield from the PHL reached $6.2 \%$ of the raw material weight.

Prehydrolysis soda-anthraquinone (AQ) cooking with a mild prehydrolysis step can be considered as an environmentally friendly sulfur-free alternative for prehydrolysis kraft cooking, with $\mathrm{AQ}$ and its derivatives comprising nucleophiles and oxidation-reduction catalysts used to replace sulfide [12]. Alaejos et al. [13] compared soda$\mathrm{AQ}$ and kraft pulping of holm oak, reporting that a lower kappa number, higher brightness level, and slightly lower viscosity were obtained for soda-AQ pulp. Moreover, the use of soda-AQ cooking eliminates the risk of environmental damage caused by sulfur emissions. As a consequence of the cooking process, lignin is dissolved from the raw material, being separated in the form of a liquor rich in phenolic compounds, which represents the process effluent. The method normally used by the pulp and paper industries to deal with the waste liquor from the kraft cooking process is recovery, concentration, and combustion. However, the lignin can be isolated and used as the starting material for a series of useful products [14, 15]. As a potential biorefinery process, the latter method is attractive; moreover, the separation of lignin following non-sulfur soda-AQ cooking is simpler and more efficient than that following kraft cooking, as the kraft cooking liquor contains sulfide, sulfite, and sulfate, which can produce toxic gases such as hydrogen sulfide and sulfur dioxide.

Several applications for the lignin obtained from cooking processes have been considered. The use of lignin for the synthesis of new polymeric materials is the most promising alternative for its revalorization. Mixing lignin with thermoplastic polymers such as polypropylene has yielded good thermal and mechanical properties [16]. Therefore, it is important to estimate weight-average molecular weight $\left(M_{\mathrm{w}}\right)$, number-average molecular weight $\left(M_{\mathrm{n}}\right)$, and the structure of lignin dissolved by the cooking process for describing the behavior of lignin more clearly to facilitate investigations of its utilization, and to optimize the method adopted in the cooking process, which influences the characteristic of the dissolved lignin [17].

Delignification capability constitutes an important technological characteristic of wood species in the cooking process, with the alkaline cooking response varying according to the hardwood species used. In our previous study, we evaluated the delignification capability of several hardwood species with various syringaldehyde $\left(\mathrm{S}_{\mathrm{a}}\right)$ to vanillin $\left(\mathrm{V}_{\mathrm{a}}\right)$ ratios (S/V ratios) by nitrobenzene oxidation of lignin [18]. Notably, the lignin structure of wood species significantly influences the final quality of DPs obtained by prehydrolysis kraft cooking and totally chlorine-free (TCF) bleaching with the sequence of oxygen bleaching $(\mathrm{O})$-peroxymonosulfuric acid treatment $\left(\mathrm{P}_{\mathrm{sa}}\right)$-alkali extraction with hydrogen peroxide bleaching $\left(\mathrm{E}_{\mathrm{p}}\right)-\mathrm{P}_{\mathrm{sa}}-\mathrm{E}_{\mathrm{p}}$. The study showed that Eucalyptus globulus wood, with the highest S/V ratio of 5.81, has the potential of producing high-quality DP using the $\mathrm{P}_{\mathrm{sa}}$ stages. Moreover, during the $\mathrm{P}_{\mathrm{sa}}$ stages, cellulose was partially depolymerized, resulting in a loss of pulp viscosity. The viscosity loss was presumed to result from the attack of hydroxyl radicals, which must be originated from residual hydrogen peroxide in the $\mathrm{P}_{\mathrm{sa}}$ stages. Thus, further research is required to investigate viscosities and pulp strength properties after the application of $\mathrm{P}_{\mathrm{sa}}$ stages in TCF bleaching [19].

As the next step to understanding and optimizing this process, in the present study we first focused on determining the characteristics of the prehydrolysis step and furfural production in the PHL using E. globulus as the selected wood species. We next compared the bleaching capability of pulps obtained by prehydrolysis soda-AQ cooking with that obtained by prehydrolysis kraft cooking, followed by a modification of $\mathrm{P}_{\mathrm{sa}}$ stages to decrease the viscosity loss. Thirdly, alkali lignin was separated from the black liquor of prehydrolysis soda-AQ cooking using different prehydrolysis and cooking conditions, and its chemical characteristics were analyzed.

\section{Materials and methods Materials}

Eucalyptus globulus and Acacia mearnsii wood chips from plantation areas in Chile and South Africa, 
respectively, were provided by Hokuetsu Corporation, Japan. $\mathrm{P}_{\mathrm{sa}}$ was synthesized in the laboratory by dropping 95\% sulfuric acid (Wako Pure Chemical Industries, Ltd., Osaka, Japan) into $45 \%$ aqueous hydrogen peroxide solution (Mitsubishi Gas Chemical Company, Inc., Tokyo, Japan) at $70{ }^{\circ} \mathrm{C}$ according to a previously reported procedure [19]. The synthesized solution contained $0.19 \mathrm{mmol} / \mathrm{L} \mathrm{H}_{2} \mathrm{SO}_{5}, 0.81 \mathrm{mmol} / \mathrm{L} \mathrm{H}_{2} \mathrm{SO}_{4}$, and $0.14 \mathrm{mmol} / \mathrm{L} \mathrm{H}_{2} \mathrm{O}_{2}$.

\section{Nitrobenzene oxidation (NBO) of the lignin in the materials} Following a modification of a previously reported method [20], approximately $200 \mathrm{mg}$ (oven-dried weight) of the prepared sample, $7.0 \mathrm{~mL}$ of $2 \mathrm{~mol} / \mathrm{L} \mathrm{NaOH}$ (Wako Pure Chemical Industries, Ltd.), and $0.4 \mathrm{~mL}$ of nitrobenzene (analytical grade, Wako Pure Chemical Industries, Ltd.) were placed in a $10 \mathrm{~mL}$ stainless steel reactor and heated to $170{ }^{\circ} \mathrm{C}$ for $2 \mathrm{~h}$. Following oxidation, $\mathrm{S}_{\mathrm{a}}$ and $\mathrm{V}_{\mathrm{a}}$ were separated from the mixture by ether extraction and then subjected to gas chromatography (GC). The GC conditions and instrumentation were as previously described [21].

\section{Chemical analysis}

The amount of acid-insoluble lignin (Klason lignin) in the materials was determined according to a modification of the TAPPI test method, T222 om-01 [22]. Extractive and ash content was determined following TAPPI test methods T204 om-88 and T211 om-93, respectively. Carbohydrate compositions were determined by ion chromatography of the filtrates of the acid hydrolysis, which had been diluted 1000 times using a Dionex ICS 3000 system (Dionex, Sunnyvale, CA, USA) equipped with a single pump (SP-1), an electrochemical detector, a CarboPac PA 1 column $(\phi 4 \mathrm{~mm} \times 250 \mathrm{~mm})$, a CarboPac PA 1 guard column $(\phi 4 \mathrm{~mm} \times 50 \mathrm{~mm})$, and an auto sampler [23]. The amount of acid-soluble lignin was determined according to TAPPI test method T222 om- 88 from the ultraviolet absorbance of the filtrate at $205 \mathrm{~nm}$ using a spectrophotometer. Kappa number, viscosity, and $\alpha$-cellulose content of the pulps were determined according to TAPPI test methods T236 om-13, T230 om-94, and T203 cm-09, respectively. The ISO brightness was measured based on TAPPI test method T452 om-92 using a digital color meter (TC-1500 SX, Tokyo-Denshoku, Japan). The hexenuronic acid (HexA) content of the pulps was determined using a high-performance liquid chromatograph (Shimadzu LC-6A HPLC) with a Zorbax ODS column: $\phi$ $4.6 \times 250 \mathrm{~mm}$ (Shimadzu, Kyoto, Japan).

\section{Prehydrolysis soda-AQ cooking}

Wood chips (50 g, oven-dried weight) were prehydrolyzed with $195 \mathrm{~mL}$ of distilled water at 150, 155, 160, 165, or $170{ }^{\circ} \mathrm{C}$ for $1.5,2.0,2.5$, or $3.0 \mathrm{~h}$. After the prehydrolysis, $130 \mathrm{~mL}$ of the PHL was separated and freeze dried. The chemical composition of freeze-dried PHL was determined according to the procedure described in chemical analysis. For furfural content determination, the PHL was distillated at $102{ }^{\circ} \mathrm{C}$, and furfural was collected into the distillate. The furfural in the distillate was analyzed using the high-performance liquid chromatograph described in chemical analysis according to a previously reported method [10]. In addition, the prehydrolyzed wood chips were subjected to soda- $\mathrm{AQ}$ cooking with $15-18 \%$ active alkali (AA) dosages at $150{ }^{\circ} \mathrm{C}$ for $3 \mathrm{~h}$, applying $0.1 \%$ dosage of AQ. The liquor-to-wood ratio was $4 \mathrm{~mL} / \mathrm{g}$.

\section{Acid catalytic dehydration and acid post-hydrolysis of PHL}

Wood chips were prehydrolyzed under different prehydrolysis conditions (time: $1.5-3.0 \mathrm{~h}$ and temperature: $150-170{ }^{\circ} \mathrm{C}$ ). Following prehydrolysis, PHL was subjected to acid catalytic dehydration by dropwise addition of concentrated sulfuric acid (95\%) to reach a final sulfuric acid concentration of $6-12 \%$. The acid catalytic dehydration reaction was implemented for $1 \mathrm{~h}$ at $98{ }^{\circ} \mathrm{C}$ under atmospheric pressure. To further hydrolyze the xylooligomers in the PHL into monomeric xylose, prior to acid catalytic dehydration of the PHL, an acid post-hydrolysis of the PHL was performed after dropwise addition of $95 \%$ sulfuric acid to reach a sulfuric acid concentration of $4 \%$. This step was conducted for $3 \mathrm{~h}$ at $100{ }^{\circ} \mathrm{C}$ under atmospheric pressure.

\section{Chlorine-free bleaching}

The TCF bleaching sequence of $\mathrm{O}-\mathrm{P}_{\mathrm{sa}}-\mathrm{E}_{\mathrm{p}}-\mathrm{P}_{\mathrm{sa}}-\mathrm{E}_{\mathrm{p}}$ was used in this research and the conditions for each stage were as follows:

(1) Oxygen bleaching $(\mathrm{O})$

Pulp consistency (PC): 30\%; oxygen pressure: $0.5 \mathrm{MPa} ; \mathrm{NaOH}$ dosage: $0.6 \%$ or $0.8 \%$; reaction temperature and time: $115^{\circ} \mathrm{C}$ for $60 \mathrm{~min}$.

(2) $\mathrm{P}_{\mathrm{sa}}$ treatment $\left(\mathrm{P}_{\mathrm{sa}}\right)$ PC: $10 \% ; \mathrm{P}_{\mathrm{sa}}\left(\mathrm{H}_{2} \mathrm{SO}_{5}\right)$ dosage for 1st stage of $\mathrm{P}_{\mathrm{sa}}$ : $0.2 \%$; that for 2 nd stage of $\mathrm{P}_{\mathrm{sa}}: 0.1 \%$; $\mathrm{pH}: 3.0$ by adding a small amount of $\mathrm{NaOH}$ to the pulp suspension; reaction temperature and time: $70{ }^{\circ} \mathrm{C}$ and $70 \mathrm{~min}$.

(3) Alkali extraction with hydrogen peroxide bleaching $\left(\mathrm{E}_{\mathrm{p}}\right)$

PC: $10 \% ; \mathrm{H}_{2} \mathrm{O}_{2}$ dosage for 1st stage of $\mathrm{E}_{\mathrm{p}}$ : $2.0 \%$; that for 2nd stage of $\mathrm{E}_{\mathrm{p}}$ : $1.0 \% ; \mathrm{NaOH}$ dosage ratio to $\mathrm{H}_{2} \mathrm{O}_{2}: 0.7 \mathrm{~g} / \mathrm{g}$; reaction temperature and time: $70{ }^{\circ} \mathrm{C}$ and $60 \mathrm{~min} ; \mathrm{MgSO}_{4}$ dosage: $0.1 \%$ (applied to maintain the pulp viscosity). 
Modification of the $\mathrm{P}_{\mathrm{sa}}$ process by mixing a small amount of chlorine dioxide $\left(\mathrm{ClO}_{2}\right)$

A small amount of $\mathrm{ClO}_{2}$ was mixed with $\mathrm{P}_{\mathrm{sa}}$ during the 1st and 2nd stages of $\mathrm{P}_{\mathrm{sa}}$. The $\mathrm{ClO}_{2}$ solution was provided from the R8 process at the pulp bleach mill, and its concentration was $7-10 \mathrm{~g} / \mathrm{L}$ as active chlorine concentration. Conditions for $\mathrm{O}$ and $\mathrm{E}_{\mathrm{p}}$ stages of the modified bleaching process were the same as described for chlorine-free bleaching. The bleaching sequence of this process was $\mathrm{O}-\left(\mathrm{P}_{\mathrm{sa}}+\mathrm{ClO}_{2}\right)-\mathrm{E}_{\mathrm{p}}-\left(\mathrm{P}_{\mathrm{sa}}+\mathrm{ClO}_{2}\right)-\mathrm{E}_{\mathrm{p}}$. The conditions for the $\left(\mathrm{P}_{\mathrm{sa}}+\mathrm{ClO}_{2}\right)$ stage were as follows:

PC: $10 \% ; \mathrm{H}_{2} \mathrm{SO}_{5}$ dosage for 1 st stage of $\left(\mathrm{P}_{\mathrm{sa}}+\mathrm{ClO}_{2}\right)$ : $0.2 \%$ (as weight); that for 2 nd stage of $\left(\mathrm{P}_{\mathrm{sa}}+\mathrm{ClO}_{2}\right)$ : $0.1 \% ; \mathrm{ClO}_{2}$ dosage for 1 st stage of $\left(\mathrm{P}_{\mathrm{sa}}+\mathrm{ClO}_{2}\right): 0.083 \%$ (as active chlorine); that for 2 nd stage of $\left(\mathrm{P}_{\mathrm{sa}}+\mathrm{ClO}_{2}\right)$ : $0.042 \%$; pH: 3.0 by adding a small amount of $\mathrm{NaOH}$ to the pulp suspension; reaction temperature and time: $70{ }^{\circ} \mathrm{C}$ and $70 \mathrm{~min}$.

\section{Preparation of purified soda lignin}

To purify the lignin, the $\mathrm{pH}$ of black liquor was adjusted to 2.0 with $20 \%$ (w/w) sulfuric acid. The solution was then centrifuged to recover the precipitate, and the precipitate was washed with distilled water. The centrifuging and washing procedures were repeated eight times. The precipitate was then vacuumed dried for $24 \mathrm{~h}$ and used as purified lignin.

\section{Structure and molecular weight distribution of purified soda lignin}

For identifying the structure of purified lignin, NBO was carried out as described above analyzed by GC. For molecular weight determination, the purified lignin powder was dissolved in $0.5 \mathrm{NaOH}$ and subjected to gel permeation chromatography (GPC), which was conducted using a Sephadex G-50 column $(\phi 18 \mathrm{~mm} \times 500 \mathrm{~mm})$ and detected with the absorbance at $280 \mathrm{~nm}$. Polystyrene sulfonic acid was used as the internal standard, and $M_{\mathrm{w}}$ was obtained by the equation: $\log _{10} M_{\mathrm{w}}=3.95-2.01 \times$ relative retention volume.

\section{Experimental design}

Experimental procedure for the whole process, including all previous sections, is shown in a flowchart (Fig. 1).

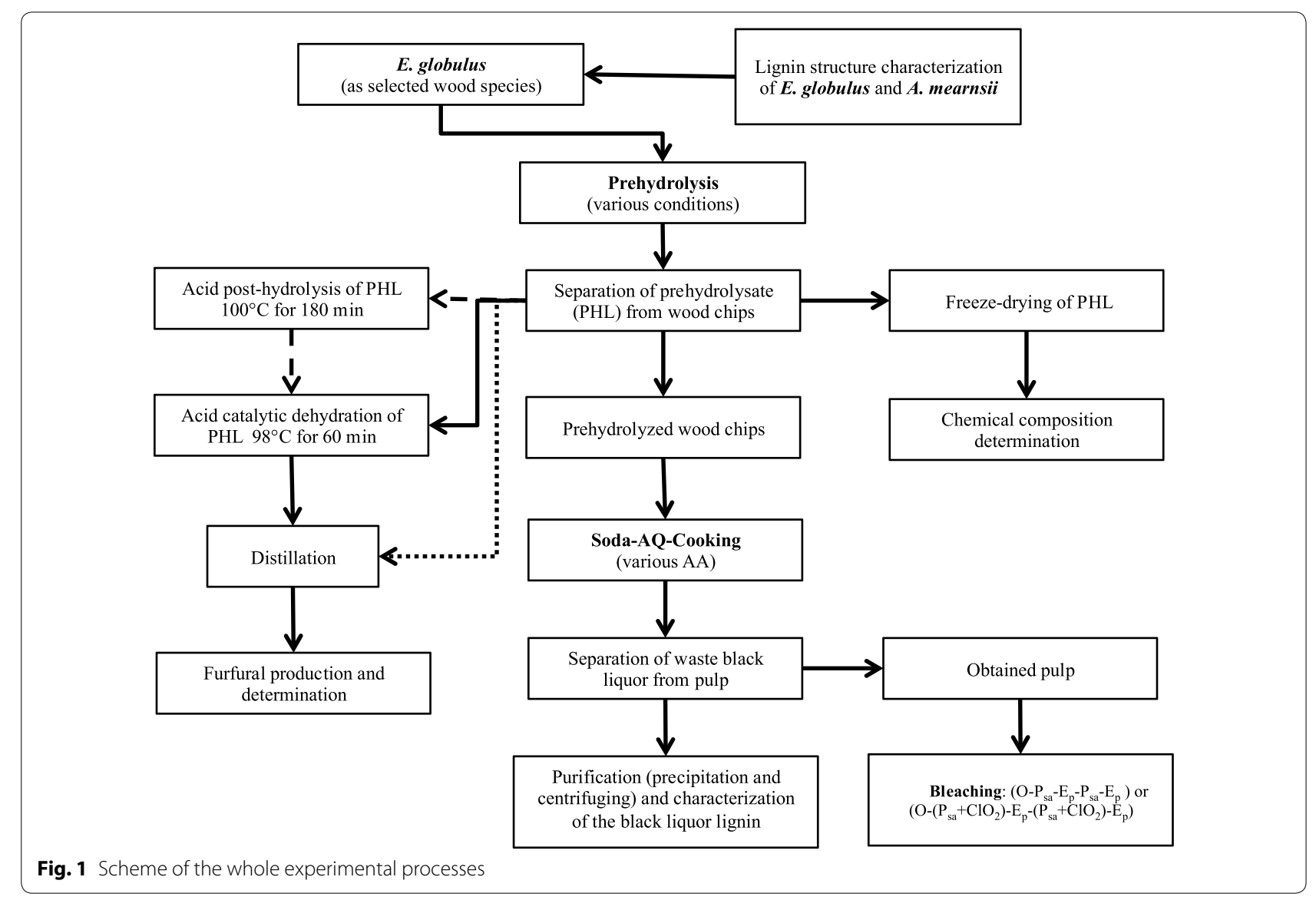




\section{Results and discussion}

\section{Characterization of the lignin structure in each wood} species

Figure 2 displays the variation of syringyl and guaiacyl nuclei in lignin as determined based on NBO among 11 to 14-year-old E. globulus (Eg11, Eg12, Eg13, Eg14, and Eg1 (a mixed sample of Eg 11-14)) and 8 to 12-year-old A. mearnsii (Am8, Am9, Am10, Am11, and Am12) woods cut from several areas of plantation with specified ages. E. globulus wood samples showed higher combined $\mathrm{S}_{\mathrm{a}}$ and $\mathrm{V}_{\mathrm{a}}$ yields and $\mathrm{S} / \mathrm{V}$ ratios than those of $A$. mearnsii samples. The $\beta-O-4$ structures, a dominant structure of lignin, have two stereoisomers: the erythro (E) form and threo $(\mathrm{T})$ forms, with a strong correlation between $\mathrm{E} /$ $(\mathrm{E}+\mathrm{T})$ and $\mathrm{S} /(\mathrm{S}+\mathrm{V})$ ratios. During the delignification reaction under alkaline condition, cleavage of the $\mathrm{E}$ form occurs dominantly compared to that of the T form [24]. Hardwoods with higher $\mathrm{S} / \mathrm{V}$ ratios are richer in $\mathrm{\beta}-\mathrm{O}-4$ structures and have higher erythro/threo ratios. Thus, a higher S/V ratio of lignin in wood results in better alkaline delignification [25]. It has been also reported that higher combined yields of $\mathrm{S}_{\mathrm{a}}$ and $\mathrm{V}_{\mathrm{a}}$ obtained by NBO suggest higher contents of non-condensed lignin [26]. Therefore, mixed wood chips of various ages of E. globulus, possessing a high $\mathrm{S} / \mathrm{V}$ ratio of 5.81 with $\mathrm{S}_{\mathrm{a}}$ and $\mathrm{V}_{\mathrm{a}}$ yields of $3.04 \mathrm{mmol} / \mathrm{g}$-lignin, were used as the raw material of this study.

\section{Behaviors of wood components during prehydrolysis soda-AQ cooking}

Table 1 shows the amounts of wood components such as hemicelluloses dissolved in PHL during the prehydrolysis at $150{ }^{\circ} \mathrm{C}$. The content of xylooligosaccharide indicated as xylan in the PHL showed a sudden increment from 2.9 to $7.2 \%$ (based on wood) after $2.5 \mathrm{~h}$ prehydrolysis. At this point, $47 \%$ of the xylan in the raw material $(15.3 \%$ of wood weight) was removed from the wood chips during the prehydrolysis. However, a further $0.5 \mathrm{~h}$ extension of the prehydrolysis time caused little increment of xylooligosaccharide dissolution in PHL (from 7.2 to $7.8 \%$ ). It has also been reported [10] that after a point, further extending the prehydrolysis time causes further hydrolysis of

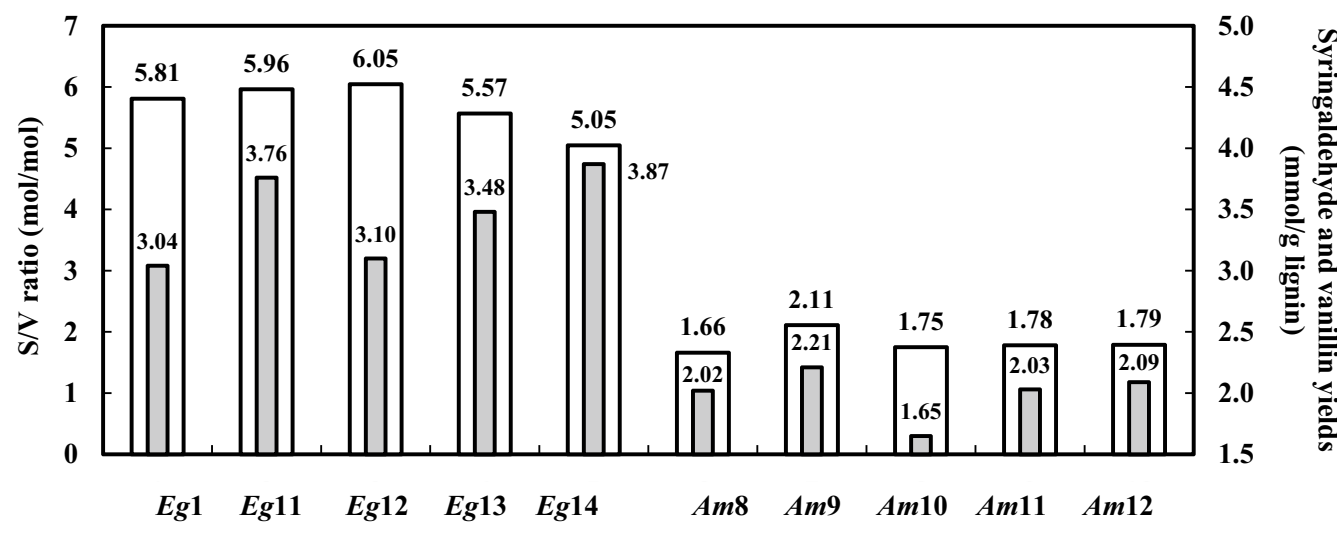

Fig. 2 Nitrobenzene oxidation of eucalyptus and acacia woods (white unfilled bars: $S / V$ ratios; gray filled bars: combined $S_{a}$ and $V_{a}$ yields). $S_{a}$ syringaldehyde; $V_{a}$ - vanillin; $S N-S_{a}$ to $V_{a}$ ratio

Table 1 Carbohydrate composition of PHLs with various prehydrolysis conditions

\begin{tabular}{|c|c|c|c|c|c|c|}
\hline Prehydrolysis time (h) & $\begin{array}{l}\text { Prehydrolysis } \\
\text { temperature }\left({ }^{\circ} \mathrm{C}\right)\end{array}$ & $\mathrm{pH}$ & $\begin{array}{l}\text { Freeze-dried solid } \\
(\%)^{\mathrm{a}}\end{array}$ & Glucan (\%) & Xylan (\%) & Others (\%) \\
\hline 1.5 & 150 & 3.3 & 6.0 & 0.03 & 2.0 & 4.0 \\
\hline 2.0 & 150 & 3.1 & 7.3 & 0.05 & 2.9 & 3.0 \\
\hline 2.5 & 150 & 3.0 & 8.4 & 0.07 & 7.2 & 1.2 \\
\hline 3.0 & 150 & 2.8 & 10.4 & 0.12 & 7.8 & 2.5 \\
\hline 2.5 & 155 & 2.9 & 9.7 & 0.28 & 7.9 & 1.5 \\
\hline 2.5 & 160 & 2.8 & 11.0 & 0.36 & 8.2 & 2.2 \\
\hline 2.5 & 165 & 2.8 & 11.5 & 0.43 & 7.8 & 2.8 \\
\hline 2.5 & 170 & 2.7 & 12.1 & 0.61 & 7.6 & 3.1 \\
\hline
\end{tabular}

a Based on raw material (acid-insoluble lignin content: $22.2 \%$, acid-soluble lignin content: $5.4 \%$, glucan content: $49.4 \%$, xylan content: $15.3 \%$ ) 


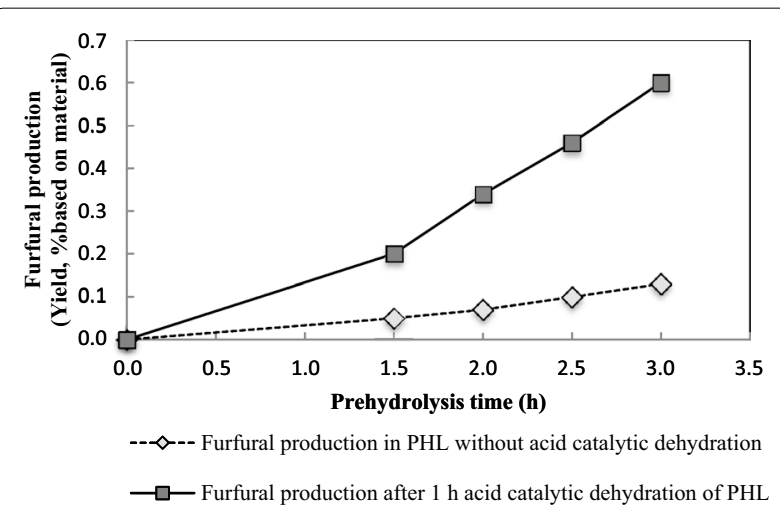

Fig. 3 Effect of prehydrolysis time on furfural production (prehydrolysis conditions: $1.5-3.0 \mathrm{~h}$ and $150^{\circ} \mathrm{C}$; dehydration conditions: $6 \%$ sulfuric acid concentration, at $98^{\circ} \mathrm{C}$ for $1 \mathrm{~h}$ )

xylose oligomers in PHL into monomeric xylose, some of which was further dehydrated to produce furfural, rather than dissolution of hemicelluloses in the wood to PHL. Moreover, the dissolution of glucan into the PHL was low $(0.12 \%$ at pretreatment for $3.0 \mathrm{~h})$, and that of lignin, not shown in Table 1, was very low.

As shown in Fig. 3, furfural content in the PHL increased gradually upon extending the prehydrolysis time at a stable rate to reach $0.13 \%$ (based on wood weight) after $3.0 \mathrm{~h}$. By adding sulfuric acid and a dehydration reaction of PHLs at $100{ }^{\circ} \mathrm{C}$ for $1 \mathrm{~h}$ with $6 \%$ sulfuric acid concentration, the furfural yield increased from 0.13 to $0.60 \%$ for the PHL obtained by $3.0 \mathrm{~h}$ prehydrolysis. However, the yield was less than one tenth of the xylooligosaccharide yield (7.8\%) in the PHL, and far lower than that obtained from nitric acid prehydrolysis of empty fruit bunch (6.2\%) in a previous study [11]. The low amount of furfural in the PHL might be due to the high amount of xylose oligomers in the PHL and acetic acid generated during the prehydrolysis, as added sulfuric acid as catalyst causes more dissolution of xylose oligomers rather than conversion of xylose monomers to furfural [10].

Next, the effect of maximum temperature of the prehydrolysis on hemicellulose removal from the raw material was investigated (Table 1). No significant difference was observed in the xylooligosaccharide yield in the PHL by increasing the temperature to $170{ }^{\circ} \mathrm{C}$. At $160{ }^{\circ} \mathrm{C}$, the yield reached the maximum point of $8.2 \%$; it can be calculated that about $54 \%$ of the xylan content of the wood $(15.3 \%$ of wood weight) was removed under this condition. The decrement of the yields at the higher temperatures might be explained by the further hydrolysis of xylose oligomers into monomeric xylose, which was partially dehydrated to produce furfural, resulting in the increment of furfural concentration in the PHL $[27,28]$. Furthermore, the final $\mathrm{pH}$ of PHL tended to decrease with the increment of temperature; this might also affect the furfural generation in PHL.

Table 2 shows the amount of furfural produced in PHL under various prehydrolysis temperatures, without and with acid catalytic reaction. Increasing the maximum temperature from 155 to $170{ }^{\circ} \mathrm{C}$ increased the amount of furfural in the PHL significantly (0.41 to $1.66 \%)$. Moreover, by adding sulfuric acid to the PHL with final concentration of $6 \%$, the furfural concentration increased after $1 \mathrm{~h}$ dehydration reaction, although this increment of furfural production in the PHL was smaller at higher temperatures. The increment of furfural production in the PHL obtained under $170{ }^{\circ} \mathrm{C}$ after $1 \mathrm{~h}$ acid catalytic dehydration reaction was from 1.66 to $1.80 \%$ of raw material weight. This result suggested that $6 \%$ sulfuric acid concentration could not significantly induce the acid dehydration reaction, likely because of the higher generation of acetic acid in the PHL during the prehydrolysis under higher maximum temperature, which catalyzes the degradation of xylooligomer to furfural during the prehydrolysis process. Thus, adding sulfuric acid with a moderate concentration of $6 \%$ was not sufficient to cause a significant increment in furfural production after $1 \mathrm{~h}$ dehydration reaction. A previous study [29] also reported that the prehydrolysis temperature, rather than the acid catalytic reaction, could significantly affect the hydrolytic pretreatment of poplar.

The effect of sulfuric acid concentration during $1 \mathrm{~h}$ dehydration reaction of the PHL obtained under prehydrolysis temperature of $170{ }^{\circ} \mathrm{C}$ is shown in Table 2 . Under these conditions, the furfural production yield increased

$\begin{aligned} & \text { Table } 2 \\
& \text { Furfural production in the PHLs without and with } \\
& \text { acid catalytic dehydration }\end{aligned}$
\begin{tabular}{llll}
\hline $\begin{array}{l}\text { Prehydrolysis } \\
\text { temperature } \\
\left({ }^{\circ} \mathbf{C}\right)^{\mathbf{a}}\end{array}$ & $\begin{array}{l}\text { Dehydration } \\
\text { reaction }(\mathbf{h})^{\mathbf{b}}\end{array}$ & $\begin{array}{l}\text { Sulfuric acid } \\
\text { concentration } \\
(\%)\end{array}$ & $\begin{array}{l}\text { Furfural } \\
\text { production } \\
\text { (Yield, \%) }^{\mathbf{c}}\end{array}$ \\
\hline 155 & - & - & 0.41 \\
160 & - & - & 0.73 \\
165 & - & - & 1.17 \\
170 & - & - & 1.66 \\
155 & 1 & 6 & 1.03 \\
160 & 1 & 6 & 1.17 \\
165 & 1 & 6 & 1.47 \\
170 & 1 & 6 & 1.8 \\
170 & 1 & 9 & 2.38 \\
170 & 1 & 12 & 2.62 \\
\hline
\end{tabular}

\footnotetext{
a Prehydrolysis time: $2.5 \mathrm{~h}$

b Dehydration temperature: $98^{\circ} \mathrm{C}$

c Based on raw material
} 
to $2.6 \%$ of the raw material weight. It was confirmed that by increasing the sulfuric acid concentration during the $1 \mathrm{~h}$ dehydration reaction, the increment of furfural concentration in the PHL obtained under $170{ }^{\circ} \mathrm{C}$ was not significant. Based on these results, we concluded that $1 \mathrm{~h}$ dehydration reaction, even with higher concentration of acid catalyst, could not be highly effective toward both the degradation of xylose oligomers into xylose monomers and conversion of xylose monomers into furfural. Therefore, for further hydrolysis of the xylose oligomers of PHL into monomeric xylose, some of which consequently are further dehydrated to produce furfural, an acid post-hydrolysis process with a milder sulfuric acid concentration of $4 \%$ for $3 \mathrm{~h}$ was conducted prior to acid catalytic dehydration. As shown in Fig. 4, acid posthydrolysis of the PHL resulted in an increment of furfural production in the PHL obtained under $170{ }^{\circ} \mathrm{C}$ up to $4.0 \%$ based on wood weight. These results supported the conclusion that conducting an acid post-hydrolysis of the

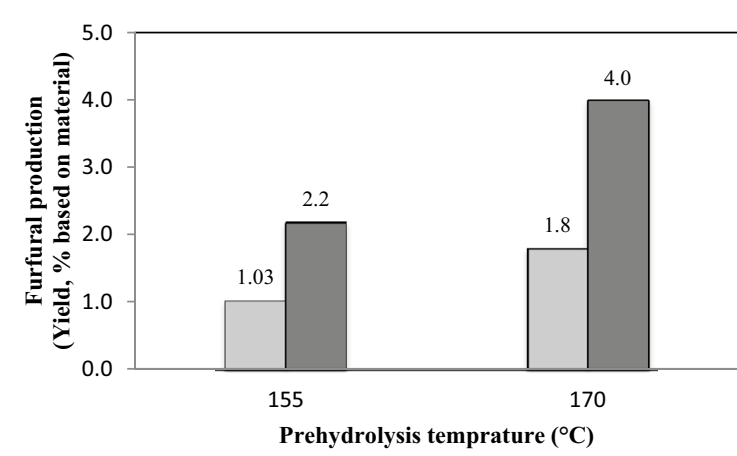

口Furfural production in PHL without acid post-hydrolysis and acid catalytic dehydration

$\square$ Furfural production in PHL after acid post-hydrolysis and $1 \mathrm{~h}$ acid catalytic dehydration

Fig. 4 Effect of acid post-hydrolysis on furfural production (prehydrolysis conditions: $2.5 \mathrm{~h}$ and $155-170{ }^{\circ} \mathrm{C}$; dehydration conditions: $6 \%$ sulfuric acid concentration, at $98^{\circ} \mathrm{C}$ for $1 \mathrm{~h}$; acid post-hydrolysis conditions: $4 \%$ sulfuric acid concentration, at $100^{\circ} \mathrm{C}$ and for $3 \mathrm{~h}$ )
PHL enhances the degradation of xylose oligomers into xylose monomers, which results in further conversion of xylose monomers into furfural in the PHL.

Considering the rather low yield and viscosity of DP, milder prehydrolysis conditions with rather high levels of hemicellulose removal function may constitute the optimum prehydrolysis conditions in the DP production processes. Testova et al. [6] reported that applying moderate prehydrolysis intensities resulted in a pulp with higher viscosity. Therefore, based on the results shown in Tables 1 and 2, for the aim of hemicellulose removal to produce a high-quality DP, prehydrolysis under $150{ }^{\circ} \mathrm{C}$ for $2.5 \mathrm{~h}$ was considered as the optimum prehydrolysis conditions in this study.

Table 3 shows the properties of the pulps provided by prehydrolysis with optimum conditions followed by two alkaline (kraft and soda-AQ) cooking processes. In particular, the kappa number, brightness and viscosity of the pulp obtained by prehydrolysis soda-AQ cooking with active alkali of $18 \%$ were almost similar to those of the pulp obtained by prehydrolysis kraft cooking with active alkali of $15 \%(8.2,47.5 \%$ ISO, $68.0 \mathrm{mPa}$ s and 8.0 , $47.2 \%$ ISO, $70.8 \mathrm{mPa}$ s, respectively). In a previous study [18], TCF bleaching of prehydrolysis kraft pulp obtained under AA of $15 \%$ resulted in a pulp with final brightness and viscosity of $90.1 \%$ ISO and $7.0 \mathrm{mPa}$ s, respectively. In the present study, we subjected the pulps obtained by the two alkaline methods (kraft and soda-AQ) to the same TCF bleaching sequence to evaluate the potential of DP production using soda-AQ cooking.

\section{TCF bleaching and characterization of obtained pulps}

Prehydrolysis kraft pulp obtained with the AA of $15 \%$ as a control and prehydrolysis soda-AQ pulps obtained with the AA of 15 and $18 \%$ were subjected to the TCF bleaching with the same sequence and conditions. As shown in Table 4, after TCF bleaching, the bleached pulp from prehydrolysis soda-AQ pulp with 15\% AA showed a lower $\alpha$-cellulose content $(92.9 \%)$ than the prehydrolysis kraft pulp with $15 \%$ AA. In addition, the

Table 3 Properties of prehydrolysis kraft and soda-AQ pulps obtained under the same conditions

\begin{tabular}{|c|c|c|c|c|c|c|c|c|}
\hline Cooking method & $\begin{array}{l}\text { AA dosage } \\
(\%)^{a}\end{array}$ & Yield (\%) & $\begin{array}{l}\text { Kappa } \\
\text { number }\end{array}$ & $\begin{array}{l}\text { Brightness } \\
\text { (\% ISO) }\end{array}$ & $\begin{array}{l}\text { Viscosity } \\
\text { (mPa s) }\end{array}$ & Glucan (\%) & Xylan (\%) & $\begin{array}{l}\text { HexA content } \\
(\mathrm{mmol} / \mathrm{kg})\end{array}$ \\
\hline Prehydrolysis ${ }^{c}$ kraft & 15 & 42.9 & 8.0 & 47.2 & 70.8 & 81.9 & 4.6 & 5.1 \\
\hline Prehydrolysis ${ }^{c}$ kraft & 18 & 41.7 & 6.5 & 49.5 & 66.8 & 85.8 & 4.1 & 5.1 \\
\hline Prehydrolysis ${ }^{c}$ soda-AQ & 15 & 42.2 & 9.0 & 45.3 & 75.1 & 79.0 & 4.5 & 4.4 \\
\hline Prehydrolysis ${ }^{c}$ soda-AQ & 18 & 41.1 & 8.2 & 47.5 & 68.0 & 83.3 & 3.9 & 4.1 \\
\hline
\end{tabular}

a Cooking conditions: $150^{\circ} \mathrm{C}$ and $3 \mathrm{~h}$

b Based on pulp

c Prehydrolysis conditions: $150^{\circ} \mathrm{C}$ and $2.5 \mathrm{~h}$ 
Table 4 Properties of $E$. globulus TCF-bleached pulp prepared under different conditions

\begin{tabular}{|c|c|c|c|c|c|c|}
\hline Cooking method & AA dosage $^{a}(\%)$ & $\begin{array}{l}\mathrm{NaOH} \text { dosage in } \mathrm{O} \\
\text { stage (\%) }\end{array}$ & a-Cellulose (\%) & $\begin{array}{l}\text { Viscosity } \\
\text { (mPa s) }\end{array}$ & $\begin{array}{l}\text { Brightness (\% } \\
\text { ISO) }\end{array}$ & $\begin{array}{l}\text { Ash } \\
\text { content } \\
(\%)\end{array}$ \\
\hline Prehydrolysis ${ }^{b}$ kraft & 15 & 0.8 & 94.2 & 7.0 & 90.1 & 0.1 \\
\hline Prehydrolysis ${ }^{\mathrm{b}}$ soda-AQ & 15 & 0.6 & 92.9 & 6.3 & 88.1 & 0.1 \\
\hline Prehydrolysis ${ }^{\mathrm{b}}$ soda-AQ & 18 & 0.6 & 94.0 & 6.0 & 88.4 & 0.1 \\
\hline
\end{tabular}

a Cooking conditions: $150^{\circ} \mathrm{C}$ and $3 \mathrm{~h}$

b Prehydrolysis conditions: $150^{\circ} \mathrm{C}$ and $2.5 \mathrm{~h}$

brightness and viscosity of the bleached soda-AQ pulp were $88.1 \%$ ISO and $6.3 \mathrm{mPa}$ s, respectively, which were lower than those of the bleached kraft pulp. By increasing the AA dosage to $18 \%$, we observed an improvement of $\alpha$-cellulose content to $94.0 \%$ along with a small viscosity loss to $6.0 \mathrm{mPa} \mathrm{s}$ (Table 4 and Fig. 5). These results demonstrated that the combined process of prehydrolysis soda-AQ and TCF bleaching with sequence of O- $\mathrm{P}_{\mathrm{sa}}-\mathrm{E}_{\mathrm{p}}-$ $\mathrm{P}_{\mathrm{sa}}-\mathrm{E}_{\mathrm{p}}$ requires some modification, especially an increment of viscosity to produce a high-quality DP. As shown in Fig. 5, after the first $\mathrm{P}_{\mathrm{sa}}$ stage, the decrement in viscosity (31.5 to $19.8 \mathrm{mPa}$ ) per unit brightness improvement (71.2 to $74.1 \%$ ISO) is much higher when compared with that after the first $\mathrm{E}_{\mathrm{p}}$ stage. It is presumed that hydroxyl radicals formed from the residual $\mathrm{H}_{2} \mathrm{O}_{2}$ would cause the viscosity loss during $\mathrm{P}_{\mathrm{sa}}$ treatment. This residual oxidant remains from the synthesis of peroxymonosulfuric acid solution, which is a mixture of $\mathrm{H}_{2} \mathrm{SO}_{5}, \mathrm{H}_{2} \mathrm{SO}_{4}$, and $\mathrm{H}_{2} \mathrm{O}_{2}$ $(0.19,0.81$, and $0.14 \mathrm{mmol} / \mathrm{L}$, respectively). As an example of this assumption, the loss of viscosity during ozone treatment is reportedly due to the reaction between carbohydrates with hydroxyl and perhydroxyl radicals generated as by-products [30].

Therefore, by adding a small amount of $\mathrm{ClO}_{2}$ to the $\mathrm{P}_{\mathrm{sa}}$ stage to decompose the residual $\mathrm{H}_{2} \mathrm{O}_{2}$ of synthesized $\mathrm{P}_{\mathrm{sa}}$ solution, following the sequences of $\mathrm{O}-\left(\mathrm{P}_{\mathrm{sa}}+\mathrm{ClO}_{2}\right)$ $\mathrm{E}_{\mathrm{p}}-\mathrm{P}_{\mathrm{sa}}-\mathrm{E}_{\mathrm{p}}$ and $\mathrm{O}-\left(\mathrm{P}_{\mathrm{sa}}+\mathrm{ClO}_{2}\right)-\mathrm{E}_{\mathrm{p}}-\left(\mathrm{P}_{\mathrm{sa}}+\mathrm{ClO}_{2}\right)-\mathrm{E}_{\mathrm{p}}$, the final viscosity of the obtained pulp improved significantly because the added $\mathrm{ClO}_{2}$ reacts readily with the excess $\mathrm{H}_{2} \mathrm{O}_{2}$ and prevents it from reacting to any significant extent with carbohydrates. The final pulp viscosity improved from 6.0 to $6.6 \mathrm{mPa} \mathrm{s}$ when a small amount of $\mathrm{ClO}_{2}(0.083 \%$ as active chlorine) was applied only to the first stage of the $\mathrm{P}_{\mathrm{sa}}\left(0.2 \%\right.$ as $\mathrm{H}_{2} \mathrm{SO}_{5}$ weight $)$, whereas by adding $\mathrm{ClO}_{2}(0.083$ and $0.042 \%$, respectively) to both stages of $\mathrm{P}_{\mathrm{sa}}(0.2$ and $0.1 \%$, respectively), the final pulp viscosity improved to $7.2 \mathrm{mPa}$ s (Fig. 6). However, under the modified bleaching process, the $\alpha$-cellulose content of the pulp did not show a significant change. The brightness, $\alpha$-cellulose content, and ash content of the bleached pulp were $90.5 \%$ ISO, $94.6 \%$, and $0.1 \%$, respectively. Table 5 shows the trends in viscosity and brightness

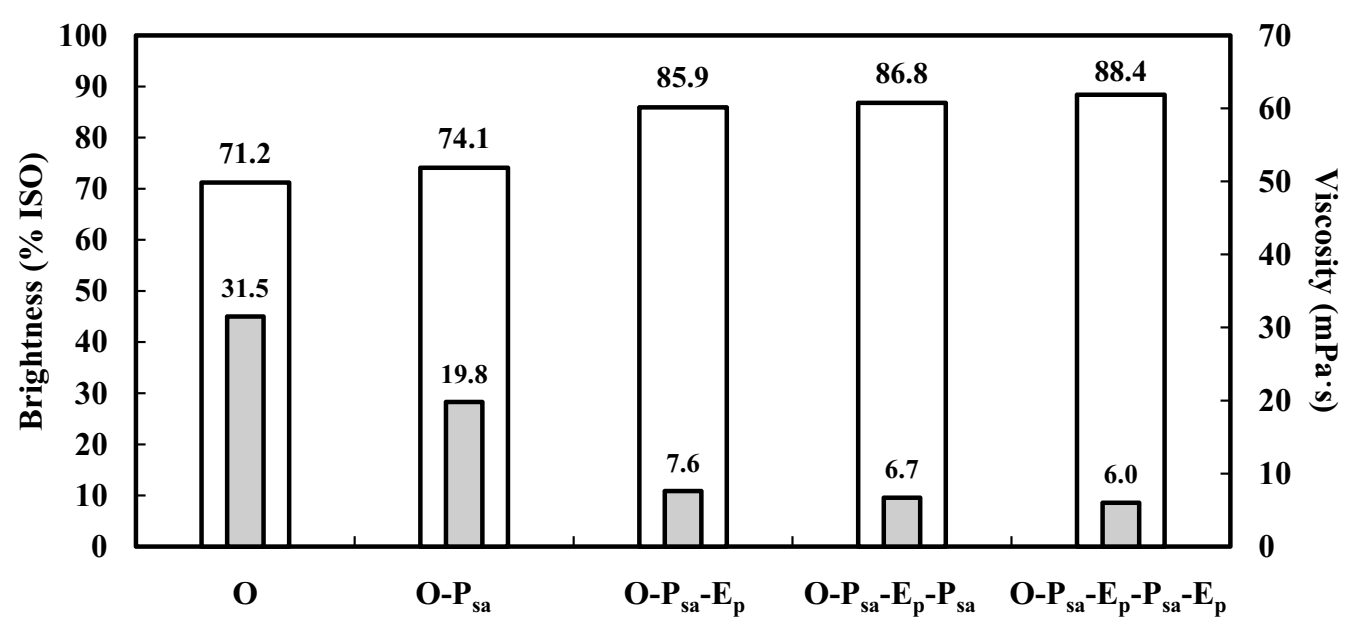

Fig. 5 Brightness and viscosity profiles during the totally chlorine-free (TCF) bleaching of E. globulus pulp (white unfilled bars: brightness; gray filled bars: viscosity). $\mathrm{O}$ —oxygen bleaching; $\mathrm{P}_{\mathrm{sa}}$ — peroxymonosulfuric acid treatment; $\mathrm{E}_{\mathrm{p}}$ —alkali extraction with hydrogen peroxide bleaching 


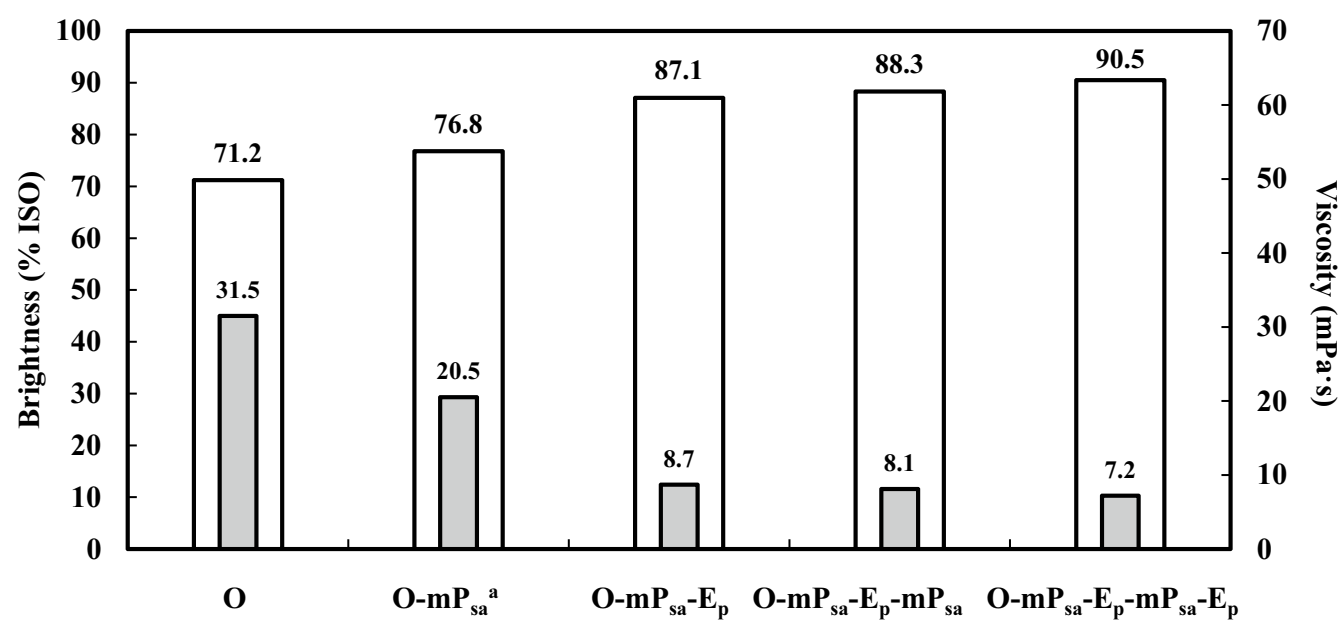

Fig. 6 Brightness and viscosity profiles during the modified TCF bleaching of E. globulus pulp (white unfilled bars: brightness; gray filled bars: viscosity). ${ }^{a}$ Modified $\mathrm{P}_{\text {sa }}$ stage with $\mathrm{ClO}_{2}$

Table 5 Properties of E. globulus soda-AQ TCF-bleached pulp, with or without $\mathrm{ClO}_{2}$ in $\mathrm{P}_{\text {sa }}$ stage

\begin{tabular}{|c|c|c|c|c|c|c|c|}
\hline Bleaching sequence & $\begin{array}{l}\text { AA dosage }^{a} \\
(\%)\end{array}$ & $\begin{array}{l}\text { Viscosity } \\
\text { (mPa s) }\end{array}$ & $\begin{array}{l}\text { Brightness } \\
\text { (\%ISO) }\end{array}$ & Glucan (\%) & Xylan (\%) & a-Celloluse (\%) & $\begin{array}{l}\text { Ash } \\
\text { content } \\
(\%)\end{array}$ \\
\hline$O-P_{s a}-E_{p}-P_{s a}-E_{p}^{b}$ & 15 & 6.3 & 88.1 & 94.0 & 4.9 & 92.9 & 0.1 \\
\hline$O-P_{s a}-E_{p}-P_{s a}-E_{p}^{b}$ & 18 & 6.0 & 88.4 & 95.4 & 2.5 & 94.0 & 0.1 \\
\hline$O-m P_{s a}-E_{p}-P_{s a}-E_{p}^{c}$ & 18 & 6.6 & 90.2 & 95.5 & 2.8 & 94.1 & 0.1 \\
\hline$O-m P_{s a}-E_{p}-m P_{s a}-E_{p}^{d}$ & 18 & 7.2 & 90.5 & 95.9 & 3.1 & 94.6 & 0.1 \\
\hline
\end{tabular}

a Cooking conditions: $150^{\circ} \mathrm{C}$ and $3 \mathrm{~h}$; Prehydrolysis conditions: $150^{\circ} \mathrm{C}$ and $2.5 \mathrm{~h}$

b Without $\mathrm{ClO}_{2}$

c With $\mathrm{ClO}_{2}$ in 1 st $\mathrm{P}_{\mathrm{sa}}$ stage

${ }^{d}$ With $\mathrm{ClO}_{2}$ in 1 st and 2 nd stages

improvement obtained by applying the modified bleaching sequence on prehydrolysis soda-AQ pulps.

\section{Characterization of purified soda-AQ lignin obtained from various prehydrolysis and cooking conditions}

The most abundant lignin substructure in wood is the $\beta-O-4$ type with two stereostructures of erythro and threo. It has been shown that $\beta-O-4$ type lignin substructures with the erythro side chain structure are removed more rapidly than those with threo side chains during alkaline delignification of wood. It is also empirically known that the $\beta-O-4$ bond of syringyl-type lignin is chemically cleaved more easily than that of guaiacyl type lignin during the alkaline delignification process [31]. Furthermore, a positive correlation between erythro/threo and syringyl/ guaiacyl ratios can be determined from the lignin structural analysis of various wood species [25]. In the present study, the structure of the purified soda-AQ lignin was defined as $S_{a}$ to $V_{a}$ molar ratio (S/V ratio) and $S_{a}$ and $V_{a}$ combined yields, determined by the NBO method.

As shown in Table 6, the increment of AA dosage decreased both the $S / V$ ratio and $S_{a}$ and $V_{a}$ yields of dissolved lignin. As explained above, the decrement of $\mathrm{S} / \mathrm{V}$ ratio of soda-AQ lignin indicates that under milder alkaline cooking conditions, the syringyl type lignin is degraded more rapidly than the guaiacyl type whereas by increasing the severity of the alkaline condition, the amount of degraded guaiacyl type lignin could be increased. In addition, in alkaline media, phenolic units of degraded lignin may react with formaldehydes, forming methylol derivatives that condense with themselves or with other phenols [32]. Therefore, the decrement of $\mathrm{S}_{\mathrm{a}}$ and $\mathrm{V}_{\mathrm{a}}$ yields in more severe alkaline conditions can be explained by greater condensation of soda-AQ lignin during the cooking process. Table 6 also indicates that the prehydrolysis process condition is not as effective on the soda-AQ lignin quality as alkaline cooking severity. In 
Table $6 \mathrm{~S} / \mathrm{V}$ ratio and combined yields of $S_{a}$ and $V_{a}$ of purified soda-AQ lignin obtained under various conditions

\begin{tabular}{llllll}
\hline $\begin{array}{l}\text { Prehydrolysis temperature } \\
\left({ }^{\circ} \mathbf{C}\right)^{\mathbf{a}}\end{array}$ & $\begin{array}{l}\text { Active alkali dosage } \\
(\mathbf{\%})^{\mathbf{b}}\end{array}$ & $\begin{array}{l}\text { Acid-insoluble lignin } \\
(\%)\end{array}$ & $\begin{array}{l}\text { Acid-soluble lignin } \\
(\%)\end{array}$ & $\begin{array}{l}\mathbf{S}_{\mathbf{a}} \text { and } \mathbf{V}_{\mathbf{a}} \text { yields }(\mathbf{m m o l} / \mathbf{g}- \\
\text { lignin) }\end{array}$ & $\begin{array}{l}\text { S/V ratio } \\
150\end{array}$ \\
\hline 15 & 84.1 & 4.1 & 0.45 & 4.9 \\
150 & 18 & 85.5 & 6.1 & 0.42 & 4.2 \\
150 & 22 & 87.2 & 6.3 & 0.33 & 2.9 \\
160 & 18 & 86.4 & 9.0 & 0.20 & 2.8 \\
170 & 18 & 88.6 & 9.4 & 0.19 & 2.9 \\
\hline
\end{tabular}

a Prehydrolysis time: $2.5 \mathrm{~h}$

b Cooking conditions: $150{ }^{\circ} \mathrm{C}$ and $3 \mathrm{~h}$

Table $7 M_{w}, M_{n}$, and polydispersity $\left(M_{w} / M_{n}\right)$ of purified soda-AQ lignin under various conditions

\begin{tabular}{lllll}
\hline $\begin{array}{l}\text { Prehydrloysis } \\
\text { temperature }\left({ }^{\circ} \mathbf{C}\right)^{\mathbf{a}}\end{array}$ & $\begin{array}{l}\text { Active alkali } \\
\text { dosage }(\%)^{\mathbf{b}}\end{array}$ & $\boldsymbol{M}_{\mathbf{w}}$ & $\boldsymbol{M}_{\mathbf{n}}$ & $\boldsymbol{M}_{\mathbf{w}} \boldsymbol{M}_{\mathbf{n}}$ \\
\hline 150 & 15 & 2029 & 826 & 2.46 \\
150 & 18 & 1653 & 667 & 2.48 \\
150 & 22 & 1559 & 678 & 2.30 \\
160 & 18 & 1828 & 696 & 2.63 \\
170 & 18 & 2050 & 712 & 2.88 \\
\hline
\end{tabular}

a Prehydrolysis time: $2.5 \mathrm{~h}$

b Cooking conditions: $150^{\circ} \mathrm{C}$ and $3 \mathrm{~h}$

particular, lignin obtained under prehydrolysis temperature of $170{ }^{\circ} \mathrm{C}$ and $18 \%$ AA showed the lowest rate of $\mathrm{S}_{\mathrm{a}}$ and $\mathrm{V}_{\mathrm{a}}$ yields of $0.19 \mathrm{mmol} / \mathrm{g}$-lignin with a rather low $\mathrm{S} / \mathrm{V}$ ratio of 2.9.

Molecular weight distribution of purified soda-AQ lignin obtained under various prehydrolysis and cooking conditions was determined using a GPC system. Soda-AQ lignin molecular weight is closely related to the number of bonds cleaved between the structural units of wood lignin during the cooking process. Guaiacyl-type lignin units are able to generate various types of $\mathrm{C}-\mathrm{C}$ bonds, especially those involving the $\mathrm{C} 5$ position of the aromatic rings, which are not easily cleaved during the cooking process owing to their higher stability; however, this is not possible in the case of syringyl-type units as they have both $\mathrm{C} 3$ and $\mathrm{C} 5$ positions substituted by methoxy groups [33]. Moreover, as previously noted, the $\beta-O-4$ bonds of syringyl type lignin are cleaved more easily and rapidly than those of guaiacyl type lignin under alkaline delignification processes [31]. As shown in Table 7, based on GPC results, the $M_{\mathrm{w}}$ of purified lignin decreased upon increasing the AA dosage owing to the enhanced degradation initially of syringyl type lignin and subsequently guaiacyl type lignin of wood, and increased by increasing the prehydrolysis temperature owing to the release of high fractions of higher molecular weight lignin from the more softened wood during alkaline cooking. Moreover,

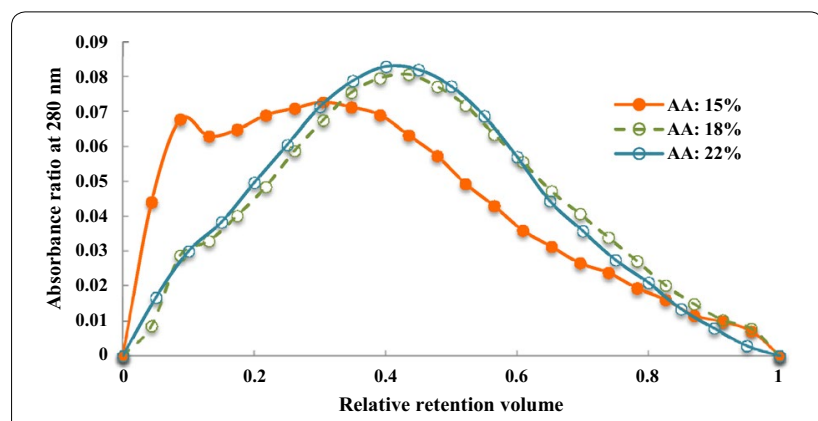

Fig. 7 Molecular-weight distribution of purified soda-AQ lignin obtained under various AA dosages (prehydrolysis conditions: $2.5 \mathrm{~h}$ at $150^{\circ} \mathrm{C}$; Soda-AQ cooking conditions: $3 \mathrm{~h}$ at $150^{\circ} \mathrm{C}$ )

it has been reported that holes that are created in the cell walls of the material after the dissolution of amorphous hemicellulose may allow the favorable penetration of chemicals during subsequent cooking [34]. Therefore, higher prehydrolysis temperatures lead to more hemicelluloses being removed from the wood and consequent exposure of a larger area of lignin to the chemicals during the subsequent cooking process, which causes the removal of lignin from the wood with greater proportions of higher molecular weight molecules. In particular, by increasing the prehydrolysis temperature from 150 to $170{ }^{\circ} \mathrm{C}$ with the same AA dosage of $18 \%, M_{\mathrm{w}}$ increased from 1653 to $2050\left(M_{\mathrm{w}} / M_{\mathrm{n}}=2.48-2.88\right.$, respectively. $)$. The molecular weight distributions of the purified sodaAQ lignin obtained under various conditions are displayed in Figs. 7 and 8.

\section{Conclusions}

In this study, the yield of xylooligosaccharide in the PHL obtained by prehydrolysis at $150{ }^{\circ} \mathrm{C}$ for $2.5 \mathrm{~h}$ reached $7.2 \%$ based on wood weight, indicating that $47 \%$ of the xylan in the wood was extracted. However, no significant difference was obtained in the xylooligosaccharide yield in the PHL by increasing the prehydrolysis temperature to $170{ }^{\circ} \mathrm{C}$. The yields of furfural obtained from the PHLs increased with acid catalytic dehydration to the range of 


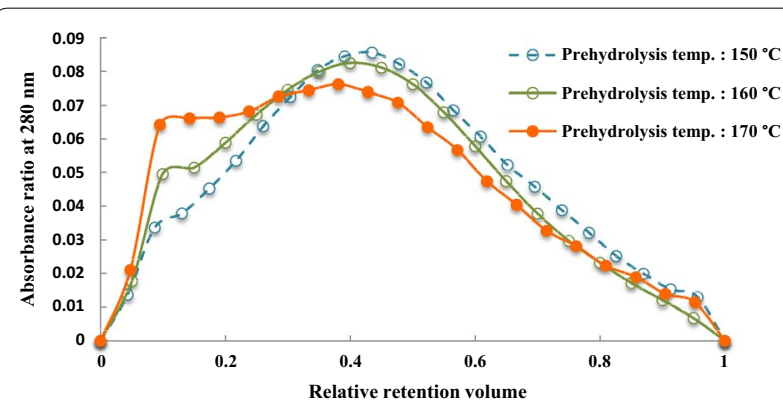

Fig. 8 Molecular-weight distribution of purified soda-AQ lignin obtained under various prehydrolysis temperatures (prehydrolysis conditions: $2.5 \mathrm{~h}$; Soda-AQ cooking conditions: $3 \mathrm{~h}$ at $150^{\circ} \mathrm{C}$, and $\mathrm{AA}$ $18 \%)$

$1.0-1.8 \%$ of wood weight. Moreover, by conducting acid post-hydrolysis of the PHL prior to acid catalytic dehydration, furfural yield could be increased to $4 \%$ of raw material weight.

When prehydrolysis soda-AQ and kraft pulps were prepared with $18 \%$ AA and bleached using the O- $\mathrm{P}_{\mathrm{sa}^{-}}$ $E_{p}-P_{s a}-E_{p}$ sequence, the final brightness and viscosity of the TCF-bleached soda-AQ pulp were $88.4 \%$ ISO and $6.0 \mathrm{mPa}$ s, respectively, which were lower than those of TCF-bleached kraft pulp prepared with 15\% AA. However, using a modified bleaching process by mixing a small amount of $\mathrm{ClO}_{2}$ with $\mathrm{P}_{\mathrm{sa}}$, the brightness and viscosity of soda-AQ pulp were increased to $90.5 \%$ ISO and $7.2 \mathrm{mPa}$ s, respectively.

Lignin obtained under prehydrolysis temperature of $170{ }^{\circ} \mathrm{C}$ and $18 \%$ AA showed the lowest rate of $S_{a}$ and $V_{a}$ yields of $0.19 \mathrm{mmol} / \mathrm{g}$-lignin with a rather low $\mathrm{S} / \mathrm{V}$ ratio of 2.9. $M_{\mathrm{w}}$ of purified lignin decreased by increasing the AA dosage and increased by increasing the prehydrolysis temperature. By increasing the prehydrolysis temperature from 150 to $170{ }^{\circ} \mathrm{C}$ with the same AA dosage of $18 \%$, $M_{\mathrm{w}}$ increased from 1653 to $2050\left(M_{\mathrm{w}} / M_{\mathrm{n}}=2.48-2.88\right.$, respectively).

Overall, the prehydrolysis soda-AQ process with a lower prehydrolysis temperature of $150{ }^{\circ} \mathrm{C}$ and a moderate AA dosage of $18 \%$ followed by a modified bleaching process with a small amount of $\mathrm{ClO}_{2}$ resulted in: (1) High rate of hemicellulose removal ( $47 \%$ of the xylan in the wood). (2) High-quality DP ( $\alpha$-cellulose content: 94.6\%, brightness: $90.5 \%$ ISO and viscosity: $7.2 \mathrm{mPa}$ s). (3) Lower lignin condensation reaction rate during alkaline cooking (higher yield of $S_{a}$ and $V_{a}$, yield of $0.42 \mathrm{mmol} / \mathrm{g}$-lignin for the lignin obtained under these conditions). (4) Lower molecular weight soda-AQ lignin, which is desirable for lignin utilization as this form is more reactive for polymerization reactions.

\section{Abbreviations}

AA: active alkali; $A Q$ : anthraquinone; DP: dissolving pulp; $E_{p}$ : alkali extraction with hydrogen peroxide bleaching; GC: gas chromatography; GPC: gel permeation chromatography; HexA: hexenuronic acid; $M_{w}$ : weight-average molecular weight; $M_{n}$ : number-average molecular weight; NBO: nitrobenzene oxidation; O: oxygen bleaching; PC: pulp consistency; PHL: prehydrolysate; $\mathrm{P}_{\text {sa: }}$ peroxymonosulfuric acid treatment; $S_{a}$ : syringaldehyde; TCF: totally chlorinefree; $V_{a}$ : vanillin.

\section{Authors' contributions}

AS had the major role in implementing the overall work including the experimental design, performing the required experiments and writing the manuscript. ASP was a major contributor in "Prehydrolysis soda-AQ cooking" part, assisting in the furfural determination experiments and writing of the part. ATR was a major contributor in "Chlorine-free bleaching" part, assisting in the design of the related experiments and writing of the part. MK was a major contributor in overall work by giving conceptual advice during the research. $\mathrm{HO}$ had the major role in supervising the overall work including giving continuous advice and support during the experimental parts and writing the manuscript. All authors read and approved the final manuscript.

\section{Author details}

${ }^{1}$ Graduate School of Life and Environmental Sciences, University of Tsukuba, Tsukuba, Japan. ${ }^{2}$ Center for Pulp and Paper, Ministry of Industry, Jl. Raya Dayeuhkolot 132, Bandung 40258, Indonesia.

\section{Acknowledgements}

This study was supported in part by Hokuetsu Corporation.

This work was presented in part at the 85th Japan TAPPI Research Conference in Tokyo, June 20-21, 2018.

\section{Competing interests}

The authors declare that they have no competing interests.

\section{Availability of data and materials}

All data generated or analyzed during this study are included in this published article.

Funding

Not applicable.

\section{Publisher's Note}

Springer Nature remains neutral with regard to jurisdictional claims in published maps and institutional affiliations.

Received: 25 September 2018 Accepted: 10 January 2019

Published online: 25 February 2019

\section{References}

1. Standard Nasional Indonesia (SNI) 0938: 2010 (2010) Pulp rayon (in Indonesian). National Standard Agency of Indonesia (BSN), Jakarta, Indonesia, http://www.sisni.bsn.go.id/index.php?/sni_main/sni/detail_sni/9701. Accessed 21 Oct 2015

2. Christov LP, Akhtar M, Prior BA (1998) The potential of biosulfite pulping in dissolving pulp production. Enzyme Microb Technol 23:70-74

3. Saeed A, Jahan MS, Li H, Liu Z, Ni Y, van Heiningen A (2012) Mass balances of components dissolved in the pre-hydrolysis liquor of kraft-based dissolving pulp production process from Canadian hardwoods. Biomass Bioenergy 39:14-19

4. Alvaro A, Rivera A, Pérez A, Yáñez R, García JC, López F (2009) Integral valorization of two legumes by autohydrolysis and organosolv delignification. Bioresour Technol 100:440-445

5. Mosier NS, Hendrickson R, Brewer M, Ho N, Sedlak M, Dreshel R, Welch G, Dien BS, Aden A, Ladisch MR (2005) Industrial scale-up of pH-controlled liquid hot water pre-treatment of corn fiber for fuel ethanol production. Appl Biochem Biotechnol 125:77-97 
6. Testova L, Borrega M, Tolonen LK, Penttilä PA, Serimaa R, Larsson PT, Sixta $H$ (2014) Dissolving-grade birch pulps produced under various prehydrolysis intensities: quality, structure and applications. Cellulose 21:2007-2021

7. Liu C, Wyman CE (2005) Partial flow of compressed-hot water through corn stover to enhance hemicellulose sugar recovery and enzymatic digestibility of cellulose. Bioresour Technol 96:1978-1985

8. Garrote G, Domínguez H, Parajó JC (2001) Kinetic modeling of corncob autohydrolysis. Process Biochem 36:571-578

9. Cai CM, Zhang T, Kumar R, Wyman CE (2014) Integrated furfural production as a renewable fuel and chemical platform from lignocellulosic biomass. J Chem Technol Biotechnol 89:2-10

10. Li H, Saeed A, Jahan MS, Ni Y, van Heiningen A (2010) Hemicellulose removal from hardwood chips in the pre-hydrolysis step of the kraftbased dissolving pulp production process. J Wood Chem Technol 30:48-60

11. Putra AS, Nakagawa-izumi A, Kajiyama M, Ohi H (2017) Biorefinery of oil palm empty fruit bunch by nitric acid prehydrolysis soda cooking. Production of furfural and dissolving pulp. Jpn Tappi J 72:641-657

12. Francis RC, Bolton TS, Abdoulmoumine N, Lavrykova N, Bose SK (2008) Positive and negative aspects of soda/anthraquinone pulping of hardwoods. Bioresour Technol 99:8453-8457

13. Alaejos J, López F, Eugenio ME, Tapias R (2006) Soda-anthraquinone kraft and organosolv pulping of holm oak trimmings. Bioresour Technol 97:2110-2116

14. Yoon K, Takahashi S, Nge TT, Karlsson O, Nakagawa-izumi A, Ohi H, Uraki Y, Yamada T (2015) Thermal melting of lignin derivatives prepared from dried black liquor powder of softwood soda-AQ cooking and polyethylene glycol. BioResources 10:912-921

15. Yoon K, Takahashi S, Nge TT, Nakagawa-izumi A, Ohi H, Yamada T (2016) Characterization of lignin derivatives in alkaline polyethylene glycoltreated soda cooking Black liquor powder. BioResources 11:6426-6437

16. Cazacu G, Pascu MC, Profire L, Kowarski AL, Mihaes M, Vasile C (2004) Lignin role in a complex polyolefin blend. Ind Crop Prod 20:261-273

17. Ohi H, Ishizu A (1989) Behavior of lignin during alkaline sulfite-quinone cooking II. Mokuzai Gakkaishi 35:748-753

18. Salaghi A, Maryana R, Ohi H (2017) Response of hardwoods consisting of various lignin structures during totally chlorine-free bleaching of dissolving pulp. In: Proceeding of 19th international symposium on wood, fibre and pulping chemistry, Porto Seguro, Bahia-Brazil, August 30-September 01, pp 24-28

19. Rizaluddin AT, Liu Q, Panggabean PR, Ohi H, Nakamata K (2015) Application of peroxymonosulfuric acid as a modification of the totally chlorine-free bleaching of acacia wood prehydrolysis-kraft pulp. J Wood Sci 61:292-298

20. Chen CL (1992) Nitrobenzene and cupric oxide oxidations. In: Lin SY, Dence CW (eds) Methods in lignin chemistry. Springer, Berlin, pp 301-306
21. Nakagawa-izumi A, H'ng YY, Mulyantara LT, Maryana R, Do VT, Ohi H (2017) Characterization of syringyl and guaiacyl lignins in thermomechanical pulp from oil palm empty fruit bunch by pyrolysis-gas chromatography-mass spectrometry using ion intensity calibration. Ind Crop Prod 95:615-620

22. Ohi H, Ju Y, Kuroda K (1997) Structure analysis of lignin by pyrolysis-gas chromatography (VII), conditions for acid hydrolysis of wood pulps and characteristics of acid-insoluble residues. Jpn Tappi J 51:1578-1586

23. Tanifuji K, Takahashi S, Kajiyama M, Ohi H, Nakamata K (2011) Advantage of acid sulfite cooking as process of bioethanol production. Jpn Tappi J 65:494-505

24. Matsumoto Y (2007) Perspective and current research trend of pulping research. Jpn Tappi J 61:769-772

25. Akiyama T, Goto H, Nawawi DS, Syafii W, Matsumoto Y, Meshitsuka G (2005) Erythro/threo ratio of $\beta-0-4-5$ structures as an important structural characteristic of lignin. Part 4: variation in the erythro/threo ratio in softwood and hardwood lignins and its relation to syringyl/guaiacyl ratio. Holzforschung 59:276-281

26. Jin Z, Jin G, Shao S, Katsumata KS (2012) Lignin characteristic of bast fiber and core in kenaf, bark and wood of paper mulberry and mulberry. J Wood Sci 58:144-152

27. Tunc MS, van Heiningen ARP (2008) Lignin carbohydrate complexes (LCC) in the autohydrolysis extract of hardwoods. In: 94th annual meeting, pulp and paper technical association of Canada, pp B451-B456

28. Shin SJ, Cho NS (2008) Conversion factors for carbohydrate analysis by hydrolysis and H-NMR spectroscopy. Cellulose 15:255-260

29. Esteghlalian A, Hashimoto AG, Fenske JJ, Penner MH (1997) Modeling and optimization of the dilute-sulfuric-acid pretreatment of corn stover, poplar and switchgrass. Bioresour Technol 59:126-136

30. Van Lierop B, Skothos A, Liebergott N (1996) Ozone delignification. In: Dence CW, Reeve DW (eds) pulp bleaching: principles and practice. TAPPI Press, Atlanta, p 32

31. Shimizu S, Yokoyama T, Akiyama T, Matsumoto Y (2012) Reactivity of lignin with different composition of aromatic syringyl/guaiacyl structure and erythro/threo side chain structures in $\beta-0-4$ type during alkaline delignification: as a basis for the different degradability of hardwood and softwood lignin. J Agric Food Chem 60:6471-6476

32. Dence CW, Lin SY (1992) Ring coupling and condensation reactions. Methods in lignin chemistry. Springer, Berlin

33. Sjöśtröm E (1981) Wood polysaccharides. Wood chemistry fundamentals and applications. Academic Press, New York, pp 51-67

34. Ma X, Huang L, Chen Y, Cao S, Chen LH (2011) Preparation of bamboo dissolving pulp for textile production. Part 1. Study on prehydrolysis of green bamboo for producing dissolving pulp. BioResources 6:1428-1439

\section{Submit your manuscript to a SpringerOpen ${ }^{\odot}$ journal and benefit from:}

- Convenient online submission

- Rigorous peer review

- Open access: articles freely available online

- High visibility within the field

- Retaining the copyright to your article

Submit your next manuscript at springeropen.com 